BNL-48909

Informal Report

GAS CONSERVATION OPPORTUNITIES IN LILCO'S COMMERCIAL SECTOR

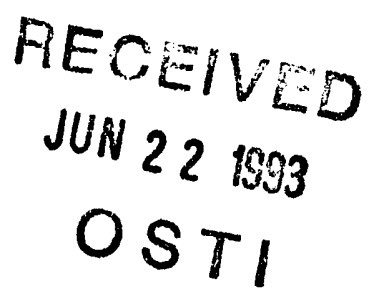

Barbara Pierce

March 1993

Energy Efficiency and Conservation Division DEPARTMENT OF APPLIED SCIENCE

BROOKHAVEN NATIONAL LABORATORY UPTON, LONG ISLAND, NEW YORK' 11973 1

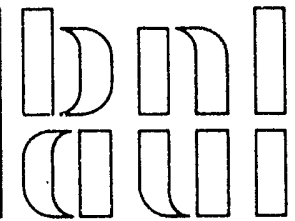




\title{
GAS CONSERVATION OPPORTUNITIES IN LILCO'S COMMERCIAL SECTOR
}

\section{Barbara Pierce}

March 1993

\author{
Energy Efficiency \& Conservation Division \\ Department of Applied Science \\ Brookhaven National Laboratory \\ Upton, New York 11973
}

This work was performed under the auspices of the U.S. Department of Energy Washington, D.C. Under Contract No. DE-AC02-76CH00016

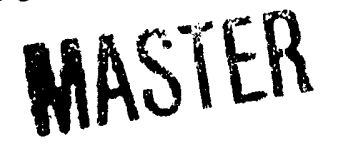




\section{DISCLAIMER}

This report was prepared as an account of work sponsored by al: agency of the United States Government. Neither the United States Government nor any agency thereof, nor any of their employees, nor any of their contractors, subcontractors, or their employees makes any warranty, express or implied, or assumes any legal liability or responsibility for the accuracy, completeness, or usefulness of any information, apparatus, product or process disclosed, or represents that its use would not infringe privately owned rights. Reference herein to any specific commercial product, process, or service by trade name, trademark, manufacturer, or otherwise, does not necessarily constitute or imply its endorsement, recommendation, or favoring by the United States Government or any agency thereof. The views and opinions of authors expressed herein do not necessarily state or reflect those of the United States Government or any agency, contractor, or subcontractor thereof. 


\begin{abstract}
This report presents the results of a preliminary investigation into opportunities for gas conservation in Long Island Lighting Company's commercial sector. It focusses on gas-fired heating equipment. Various sources of data are examined in order to characterize the commercial buildings and equipment in the service territory. Several key pieces of information necessary to predict savings potential are identified. These include the efficiencies and size distribution of existing equipment. Twenty-one specific conservation measures are identified and their applicability is discussed in terms of equipment size. Recommendations include improving the characterization of existing buildings and equipment, and developing a greater understanding of the savings and costs of conservation measures, and their interactions, especially in the middle size range of buildings and equipment.
\end{abstract}




\section{ACKNOWLEDGMENTS}

The efforts of John Batey of Facility Energy Services, Inc. in preparing the appendix and the discussion of conservation measures are gratefilly acknowledged. Discussions with J.M. MacDonald of Oak Ridge National Laboratory were informative and helpful. The assistance of LILCO staff, particularly Pat Smolenski and Linda Zappulla, is also appreciated. 


\section{TABLE OF CONTENTS}

\section{Page}

ACKNOWLEDGMENTS $\ldots \ldots \ldots \ldots \ldots \ldots \ldots \ldots \ldots \ldots \ldots$ iv

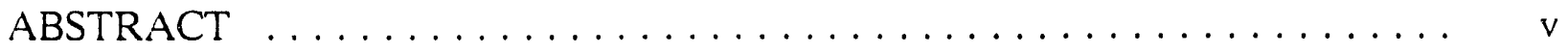

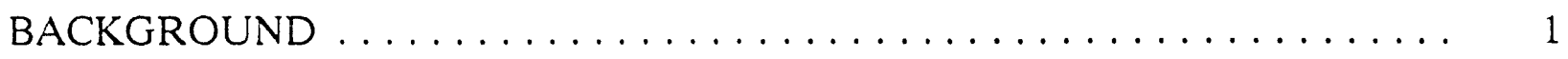

COMMERCIAL SECTOR CHARACTERIZATION $\ldots \ldots \ldots \ldots \ldots \ldots$

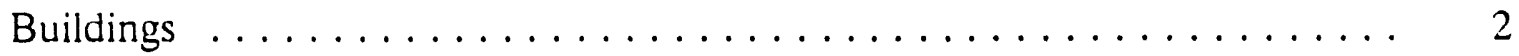

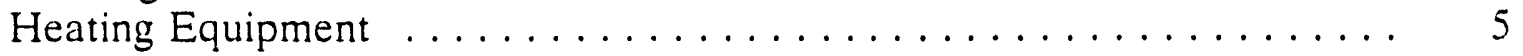

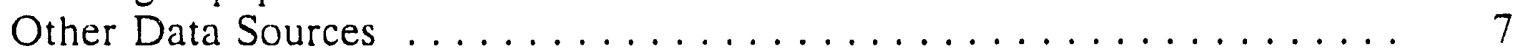

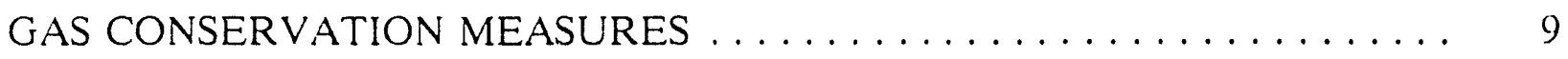

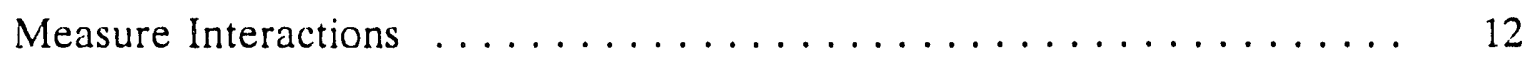

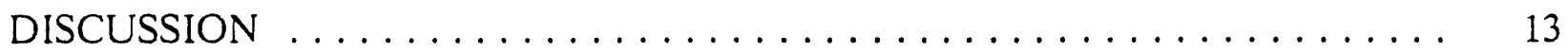

RECOMMENDATIONS ....................... 14

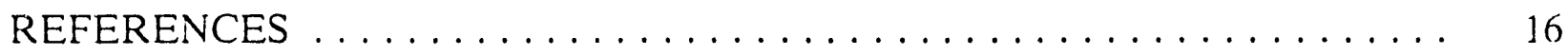

APPENDIX A. CONSERVATION MEASURE DESCRIPTIONS 
TABLES

Page

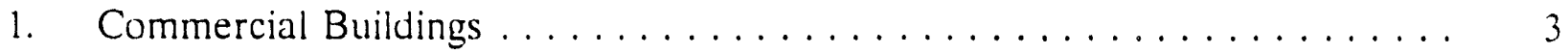

2. Building Activity and Operating Hours, Northeast ............. 4

3. Present of Conservation Features in Commercial Buildings, Northeast ............................. 6

4. Energy Conservation Options for Commercial Gas Heating Equipment ............................. 10 


\section{GAS CONSERVATION OPPORTUNITIES IN LILCO'S COMMERCIAL SECTOR}

The Long Island Lighting Company (LILCO) is considering expanding its conservation activities to include gas-fired applications, as are other gas and combined utilities in New York and elsewhere. New demand-side management (DSM) programs will focus on improving the efficiency of gas use in the residential, commercial, and industrial sectors.

The commercial sector is the most complex and least understood of the sectors. Many types of buildings are included in the commercial sector, with sizes ranging from less than 1,000 square feet to greater than 500,000 square feet. Energy-using equipment also reflects the diversity of business types and sizes. This report examines what is known about LILCO's commercial sector and identifies some of the conservation options available to LILCO for its gas DSM programs.

\section{BACKGROUND}

Two recent studies have estimated the potential for gas conservation in LILCO's service territory, using two different approaches. The first (Hampton Strategies, Inc.) estimated conservation potential on the basis of DSM programs. Prototype programs (audit, weatherization, etc.) were defined based on experiences of other utilities. Estimates of savings potential were then estimated using both other utilities' experiences and LILCOspecific data.

The second study (Nadel et al.) was designed to estimate the technically achievable gas conservation potential for all of New York State. LILCO's service territory was used to represent down-state potential. Prototype buildings and specific conservation measures were defined and savings potential determined by computer modelling of each measure in each building type.

This study took a different approach to identifying areas of conservation potential in the commercial sector. We examined several sources of data in order to characterize the buildings and equipment in LILCO's commercial sector. Next, we identified 21 conservation measures for gas-fired heating equipment. Two important results were achieved. First, we characterized the applicability of the heating system measures by equipment size. Second, we identified several key pieces of information that LILCO needs to confidently predict savings potential in the commercial sector.

\section{COMMERCIAL SECTOR CHARACTERIZATICN}

The first step in estimating the potentiai for gas conservation is to characterize existing buildings and equipment. This section examines several sources of data to determine their usefulness in providing an understanding of LILCO's commercial sector. 


\section{Buildings}

DOE's Commercial Buildings Energy Consumption Survey (CBECS) is a national survey of commercial buildings characteristics and energy use conducted every 3 years by the Energy Information Administration. Selected data from the 1989 CBECS are compared to LILCO data to determine whether CBECS data could serve as a surrogate if LILCO-specific data are not available, as shown in Table 1 .

The table shows several categories of data by Census Division. Both New England and MidAtlantic data are given for comparison. Comparable LILCO data are the percent of (electric) accounts by square footage and by number of workers. LILCO data are similar to the percent of buildings by these categories, suggesting that CBECS data may be useful as a rough approximation of LILCO's service territory.

Most of the buildings and businesses are small. About 70 percent of the buildings are 10,000 square feet or smaller and have fewer than 10 workers. The larger buildings, though fewer, account for a much greater percentage of total floorspace. Building size distribution is important for two reasons. First, small buildings behave more like residential buildings. Energy demand is more likely to be affected by the weather, whereas energy use in large buildings is often dominated by internal loads. The energy-using equipment in small buildings is more likely to be in the residential size range. Effective energy conservation measures may differ depending on building and equipment size.

Second, the larger buildings account for a greater share of total energy consumption. At the national level, large buildings (greater than 100,000 square feet) account for about one-third of all energy consumption and the same percent of commercial sector natural gas consumption. In the Northeast, large buildings consume more than 40 percent of all energy and natural gas. This has implications for demand-side management program design. A utility is likely to save the most energy at the least cost by focussing on larger energy users, the largest buildings. But programs that focus only on large buildings will reach only a few customers and ignore large segments of the commercial population.

The last two sections of Table 1 show the types of wall and roof materials used in commercial buildings. The type of construction will determine what shell measures will be appropriate and cost-effective. Most of the buildings have masonry walls, but about onequarter have siding or shingles. The Northeast shows more shingles on roofs than the country as a whole; for the U.S., 35.6 percent $\Omega \ddot{i}$ commercial buildings have built-up roofs and 30.7 percent have shingles. Further examination of CBECS data could provide construction details by building size. However, LILCO's service territory may differ from the Northeast.

The type of business is also an important determinant of energy use. Restaurants and hospitals, for example, use large quantities of hot water, presenting opportunities for significant energy savings. Some types of businesses operate 24 hours a day, limiting the savings potential of thermostat setback measures but increasing the potential for other measures. Table 2 shows the percent of buildings and floorspace by building activity and 


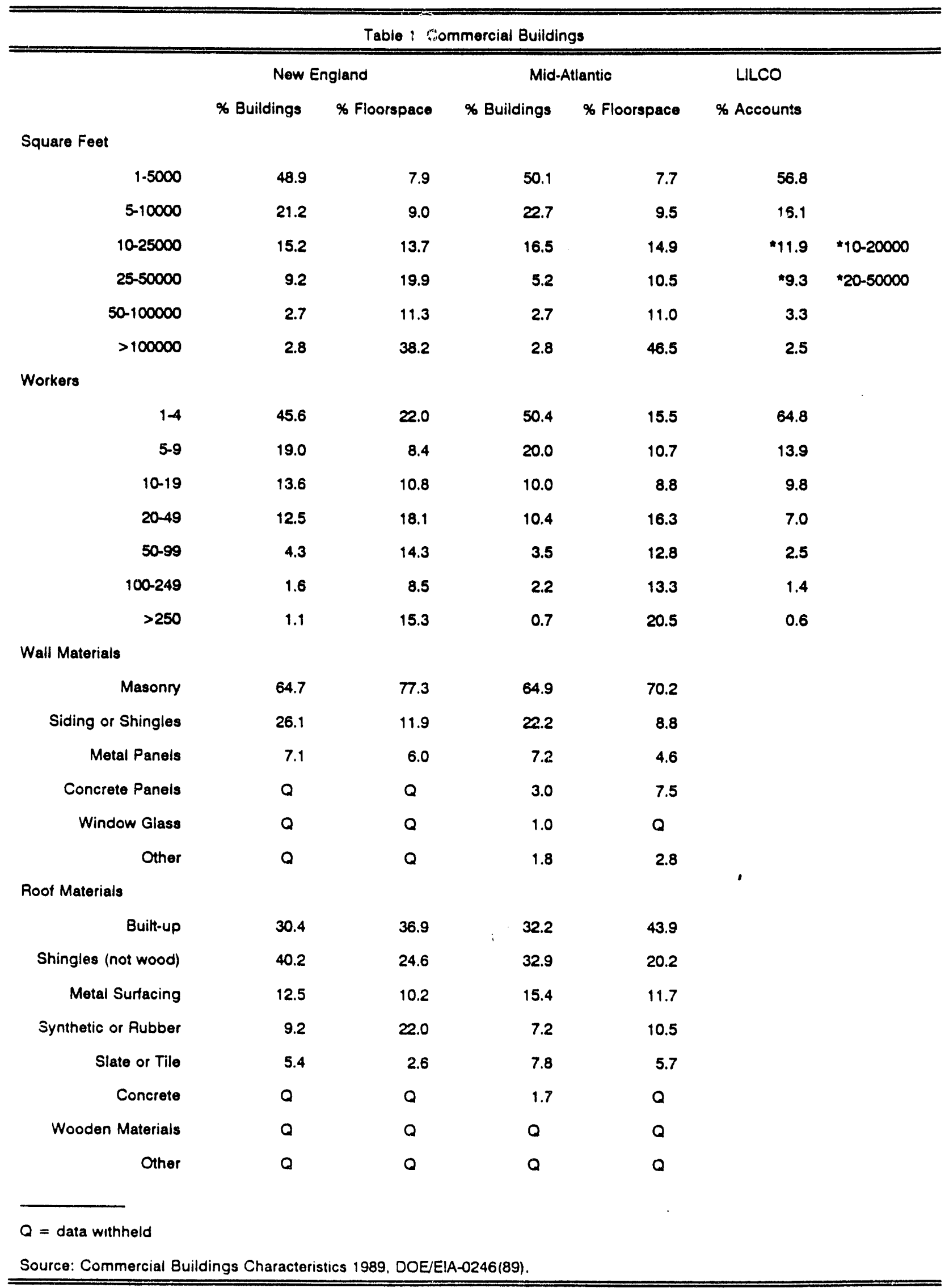


Building Activity and Operating Hours, Northeast

\begin{tabular}{|c|c|c|}
\hline & \% Buildings & \% Floorspace \\
\hline \multicolumn{3}{|l|}{ Building Activity } \\
\hline Assembly & 12.3 & 11.1 \\
\hline Education & 4.8 & 13.9 \\
\hline Food Sales & 0 & $Q$ \\
\hline Food Service & 6.9 & 2.1 \\
\hline Health Care & 1.5 & 2.8 \\
\hline Lodging & 2.9 & 4.0 \\
\hline Mercantile and Service & 33.1 & 19.5 \\
\hline Office & 13.8 & 19.9 \\
\hline Parking Garage & 2.0 & 1.2 \\
\hline Public Order and Safety & Q & $Q$ \\
\hline Warehouse & 12.1 & 13.3 \\
\hline Other & 1.5 & 1.2 \\
\hline Vacant & 5.7 & 6.7 \\
\hline \multicolumn{3}{|l|}{ Weekly Operating Hours } \\
\hline 39 or fewer & 14.4 & 7.2 \\
\hline 40 to 48 & 21.1 & 19.2 \\
\hline 49 to 60 & 22.2 & 20.6 \\
\hline 61 to 84 & $\$ 17.2$ & 22.0 \\
\hline 85 to 167 & 15.8 & 17.4 \\
\hline Open continuously & 9.2 & 13.5 \\
\hline$Q=$ data withheld & & \\
\hline Source: Commercial Build & Es 1989, DOE/ & $246,89)$ \\
\hline
\end{tabular}


operating hours for the Northeast, taken from CBECS. It may be possible to aggregate LILCO customer data (by SIC codes) to the categories used in CBECS to verify similarities between LILCO's service territory and the Northeast region.

Table 3 shows CBECS data on conservation features present in commercial buildings in the Northeast. While two-thirds of the buildings have roof or ceiling insulation, the amount of insulation is not given. Nonetheless, the data in the table give a general indication of opportunities for conserving energy. Fewer than half of the buildings have wall insulation or storm windows. When cost-effective, these measures can significantly improve energy efficiency. Although only a small percent of buildings have a computerized energy management control system, these systems are more common in larger buildings. For the U.S., 37 percent of buildings greater than 100,000 square feet have some kind of control system. If LILCO-specific data are not available, further evaluation of CBECS data could correlate conservation features with building size and other important characteristics.

\section{Heating Equipment}

LILCO has conducted audits of its commercial buildings for a number of years. The data, however, do not reside in-house, and currently only a limited amount of information from the audits is available. Available information does include an equipment inventory report (XENERGY). Data from the audit database were post-stratified and weighted using electricity billing data to reflect the population of commercial accounts. The heating equipment data from that report are examined in this section.

Gas-fired equipment represents about 30 percent of total heating system capacity in the commercial sector. Boilers account for almost 40 percent of the gas-fired heating equipment, and rooftop units for an additional 23 percent. Furnaces and unit heaters each account for 18 percent.

The office sector represents the largest share of gas capacity, followed by the retail and industrial sectors. Although only 16 percent of the total gas capacity is in the retail subsector, over 50 percent of the heating capacity in that sector is gas-fired. Restaurants represent only a small part of total installed gas capacity, but over 50 percent of the heating equipment in restaurants is gas-fired.

Overall, boilers account for 39 percent of the commercial sector's gas-fired heating equipment capacity. In schools and health facilities, however, boilers represent about 90 percent of the gas-fired capacity. In several other subsectors (office, hotels, industrial, other, and not elsewhere classified) boilers account for between one-third and one-half of existing gas-fired heating equipment.

Boiler size is a key determinant of the types of retrofit measures which are appropriate for improving efficiency. Equipment size distribution data are not included in the report; total capacity and the number of units by type allow calculation of average sizes. Steam boilers are, on average, larger than hot water boilers. Average size ranges from $375 \mathrm{MBtuh}$ in 


\begin{tabular}{|c|c|c|c|}
\hline \multicolumn{4}{|c|}{$\begin{array}{l}\text { Table } 3 \\
\text { Presence of Conservation Features in Commercial Buildings, Northeast }\end{array}$} \\
\hline & \% Buildings & $\%$ Floorspace & \\
\hline \multicolumn{4}{|l|}{ Building Shell } \\
\hline roof/ceiling insulation & 66.5 & 65.2 & \\
\hline wall insularion & 46.4 & 44.4 & \\
\hline storn or multiple glazing & 45.9 & 45.2 & \\
\hline weatherstripping or caulking & 64.0 & 72.8 & \\
\hline \multicolumn{4}{|l|}{ Heating Temperature Control } \\
\hline Any occupant control & 58.4 & 41.4 & $\begin{array}{l}\text { (\% of heated buildings } \\
\text { and floorspace) }\end{array}$ \\
\hline vy thermostat & 53.9 & 38.8 & \\
\hline Reduced off-hours & 79.3 & 77.9 & \\
\hline \multicolumn{4}{|l|}{ Cooling Temperature Control } \\
\hline Any occupant control & 62.6 & 51.2 & (\% of cooled buildings \\
\hline by thermostat & 58.2 & 48.6 & \\
\hline Reduced off-hours & 87.2 & 85.9 & \\
\hline \multicolumn{4}{|c|}{ Computerized Energy Management Control Systems } \\
\hline Any & 5.6 & 23.6 & \\
\hline Controls HVAC & 5.5 & 22.8 & \\
\hline Controls Lighting & 1.1 & 5.6 & \\
\hline Control Other & 0.8 & 4.1 & \\
\hline Regular HVAC maintenance & 58.1 & 75.6 & \\
\hline Source: Commercial Buildings & teristics 1989, & $E / E I A-0246(89)$ & \\
\hline
\end{tabular}


restaurants to $7,973 \mathrm{MBtuh}$ in health facilities. The average size of hot water boilers ranges from 212 MBtuh in hotels to 2,362 MBtuh in schools.

Warm air and duct furnaces represent almost 18 percent of existing gas-fired capacity. A duct furnace is located directly in the duct and is generally used to heat a special zone or to boost supply temperatures. It heats air directly, not in a plenum like a warm air furnace. There are more furnaces than boilers in the commercial sector, but the average size is much smaller, around $170 \mathrm{MBtuh}$.

There are nearly 16,000 rooftop units, which account for 23 percent of commercial sector gas-fired heating equipment. Most of these are in the office, retail, grocery, restaurant, and warehouse subsectors.

A unit heater is usually located in the zone it heats and uses no outside air. There are almost 16,000 unit heaters in LILCO's commercial sector, and they account for about 18 percent of existing gas-fired heating capacity. The office, retail, and industrial subsectors each account for more than 20 percent of the unit heater capacity, and warehouses represent about 15 percent of the total.

CBECS also contains data on energy-using equipment in commercial buildings, but a comparison with the inventory data was not possible. CBECS reports the number of buildings with particular equipment and the inventory report gives the total units of each type of equipment.

This section described the gas-fired heating equipment in LILCO's commercial sector. We focused on heating equipment because the largest share of energy use is for heating, and because more data are available on heating equipment. To provide accurate estimates of conservation potential, several key pieces of additional information are necessary. These include the age, efficiencies, and size distribution of existing equipment, information about distribution systems, the number of multi-boiler facilities, and how non-heating loads (process or domestic hot water) are met.

\section{Other Data Sources}

Other potential sources of data were identified but detailed examination of them was outside the scope of this initial project. The first is New York's Institutional Conservation Program (Hill and Kroon). This program provides technical assistance and grants to institutional buildings, primarily schools and hospitals. A number of these studies have taken place on Long Island. If detailed data, case studies or evaluations exist, they could provide valuable insights to potential gas savings as well as help validate characterizations of these subsectors.

The second is the data base that has been compiled from audits provided by the Energy Advisory Service to Industry (EASI), sponsored by the New York State Energy Office. This program offers free on-site surveys to firms of less than 400 employees in commerce, industry, a id agriculture. From 1987 to 1990, more than 3,000 EASI surveys were performed in New York. Over 500 of these were done in Nassau and Sutfolk Counties. More than 200 
energy conservation measures are considered, addressing all tuels. A preliminary analysis of EASI data has been performed for different purposes (Hill and Kroon); these data are available for further analysis which could help target certain subsectors with large potential savings.

LILCO has conducted numerous audits of its commercial buildings. The audits have focused primarily on electric end uses and recommendations for improving the efficiency of electricity use. LILCO does not maintain the data base in-house, but receives regular summary reports. LILCO may also request additional detailed analyses, as desired.

The form used to collect data was reviewed to determine if data relevant to gas conservation might be available and to recommend additional data to collect in future audits specifically for gas end-uses. It was found that the form could be significantly improved by more complere recording of the presence or absence of certain features. For example, although installation of an energy management control system (EMCS) may be recomınended, auditors currently do not report whether the building has such a system. Thus, if an EMCS is not recommended, there is no way to determine if an EMCS is already present in the building.

A number of other recommendations for additional data collection were made; these focussed primarily on heating plant and HVAC equipment in buildings where gas is used for heating. Heating accounts for the largest amount of energy used in commercial buildings, and combustion equipment represents the biggest challenge for a combined utility that has previously focused only on electric end uses. It is recommended that combustion efficiency tests be performed in all gas-heated buildings; it is recognized that existing conditions may make this difficult.

Collection of some of the data which could be useful in characterizing the commercial sector is currently optional; LILCO is assessing whether enough optional data have been collected to make a detailed report on gas customers worthwhile. Another consideration in determining the usefulness of the audit data is its age; occupancy and equipment changes occur frequently enough in the commercial sector that care must be taken with data that is more than several years old.

Another resource would be the use of billing data to examine gas use in LILCO's commercial buildings. Depending on the form and quality of the data, it may be possible to perform a fairly simple analysis to target particular buildings or customer segments for conservation programs, or to develop prototypes for further analysis.

If square footage data are also available, it would be possible to determine the range of gas use by business type, size and rate class. Customers at the high end of their category could be targeted for audits and conservation measures. If this information is provided to customers, it can provide motivation for participating in conservation programs. This approach has been successfully used with owners of multi-family buildings in New York City (Goldner). 
Finally, if LILCO decides to explore analysis with prototype buildings there are several other projects which may be of interest.

The Gas Research Institute (GRI) has sponsored at least two efforts which include commercial sector categorization or development of commercial building prototypes. One of these (Briggs) categorized the nation's office buildings to help GRI plan its R\&D program. This effort used cluster analysis to categorize the nation's office buildings. Category descriptions were then used to create input files for computer simulation (Crawley and Huang). The second effort created 13 building prototypes for thirteen climate regions to assess the potential for cogeneration (Huang et al.) This study focused on urban areas where the potential for cogeneration was judged to be high. Hourly energy profiles were then simulated.

DOE's Office of Conservation and Renewable Energy (CE) is currently evaluating the use of prototype buildings for policy analysis and research planning (Stucky and Belzer). This effort will begin with office and retail buildings, which represent the largest share of LILCO's zas-fired heating capacity. This effort will use CBECS data and cluster analysis, followed by detailed simulation analyses.

$\mathrm{CE}$ also sponsors a building retrofit program. Although most of the focus has not been on commercial buildings, the program has sponsored some prototype and simulation analysis and has developed monitoring protocols for commercial buildings (MacDonald et al.).

It may be possible to extract a sample of representative buildings from one or more of the prototype data sets described above to use in engineering simulations of retrofit measures. Simulations could be verified with field monitoring of actual retrofits in LILCO's service territory. Field monitoring is especially important when installing more than one measure, due to interactions among measures.

\section{GAS CONSERVATION MEASURES}

This section presents a general discussion of gas conservation measures that are appropriate for LILCO's commercial sector. It focusses on heating equipment measures because most gas is used for heating and therefore the potential for savings is high, and because more data are available on heating equipment.

Table 4 shows some of the conservation options available for gas-fired heating equipment. Commercial buildings include a wide range of heating equipment sizes that have been divided into three general classifications for this preliminary assessment of energy conservation opportunities. Savings estimates are for gas only; electricity savings are not included. The appendix contains detailed descriptions of the options.

Class I represents small buildings with heating equipment sizes of up to 300,000 Btu per hour. This equipment will have a fixed firing rate, and is similar in design and operation to residential space heating equipment. It is expected that many of the energy conservation options that are available for residential gas equipment will also be applicable to equipment 
Table 4.

Energy Conservation Options tor Commercial Gas Heating Equipmen*

\begin{tabular}{|c|c|c|c|c|c|c|}
\hline \multirow[b]{2}{*}{ Option } & \multirow[b]{2}{*}{$\begin{array}{l}\text { Savings } \\
(\%)\end{array}$} & \multirow[b]{2}{*}{$\begin{array}{l}\text { Approx. } \\
\text { Cost' } \\
(\$)\end{array}$} & \multirow[b]{2}{*}{$\begin{array}{c}\text { Payback } \\
\text { Range } \\
\text { (yrs.) }\end{array}$} & \multicolumn{3}{|c|}{ Class' } \\
\hline & & & & 1 & $\|$ & III \\
\hline Vent Dampers & $5-10$ & 200 & $1-7$ & $\checkmark$ & $\mathbf{S}^{* *}$ & \\
\hline Power Vent & $3-9$ & 150 & $1-8$ & $\checkmark$ & & \\
\hline Electric Ignition & 5 & 175 & $1-6$ & $\checkmark$ & & \\
\hline Boiler Water Temp. Reduction & $5-12$ & 350 & $2-11$ & $\checkmark$ & $\checkmark$ & \\
\hline Boiler Jacket Insulation & $1-5$ & 45 & $1-10$ & $\checkmark$ & $\checkmark$ & $\checkmark$ \\
\hline Economizer - Boiler & $10-20$ & $400-\{300$ & $2-11$ & $\checkmark$ & $\checkmark$ & $\checkmark$ \\
\hline Pipe/Duct Insulation & $2-20$ & $100-200$ & 1.8 & $\checkmark$ & $\checkmark$ & $\checkmark$ \\
\hline Power Burners & 15 & 300 & $2-3$ & $\checkmark$ & $s^{* *}$ & \\
\hline Combustion Air Preheat & 5 & varies & varies & & $S^{* *}$ & $\checkmark$ \\
\hline Zoning & $10-30$ & $100-500$ & $1-5$ & $\checkmark$ & $s^{* *}$ & \\
\hline Automatic Setback Thermostat & 8 & $50-150$ & $1-2$ & $\checkmark$ & $s^{* *}$ & \\
\hline High Efficiency Boiler/Furnace & $20-40$ & $1500-3000$ & $3-10$ & $\checkmark$ & & \\
\hline Ventilation Air - Manual/EMS & $5-25$ & - & $1-2$ & & $s^{* *}$ & $\checkmark$ \\
\hline Bldg. Temp. Control - EMS & $5-30$ & - & $2-4$ & & $S^{*}$ & $\checkmark$ \\
\hline Hot Deck Reset - EMS & $5-10$ & - & $2-4$ & & $S^{* *}$ & $\checkmark$ \\
\hline Burner Efficiency Adjustment & $2-8$ & - & $0-1$ & & $\checkmark$ & $\checkmark$ \\
\hline Oxygen Trim Controls & 4-10 & - & $3-5$ & & & $\checkmark$ \\
\hline Boiler Plant Optimization & $10-20$ & - & $1-2$ & & $\mathrm{~s}^{* \bullet}$ & $\checkmark$ \\
\hline Burner Replacement & $5-15$ & - & $2-4$ & & $S^{* *}$ & $\checkmark$ \\
\hline Boiler Replacement (Partial) & $10-30$ & - & $2-6$ & & & $\checkmark$ \\
\hline Boiler Replacement (Complete) & $10-30$ & - & $3-10$ & & $S^{* *}$ & $\checkmark$ \\
\hline \multicolumn{7}{|c|}{ ' Costs will vary significantly for Classes II and III. } \\
\hline $\begin{aligned} \text { Size Classifications: } & \text { I-Small } \\
& \text { II - Mid-S } \\
& \text { III - Larg }\end{aligned}$ & $\begin{array}{l}\text { p to } 300 \text { A } \\
\text { e: } 301 \text { to ? } \\
\text { Above } 2,0\end{array}$ & $\begin{array}{l}\text { Btuh } \\
000 \text { MBtuh } \\
0 \text { MBtuh }\end{array}$ & & & & \\
\hline * $\mathrm{S}=$ Sometimes applicable & & & & & & \\
\hline
\end{tabular}


in these small buildings. It is anticipated that the energy savings, equipment costs, and payba. . neriods will be similar to residential energy conservation options.

Most of the commercial floorspace in LILCO's service territory falls into this category. Based on average equipment sizes, it is likely that most of the furnaces and rooftop units as well as some hot water boilers are in this size range. Conservation options include vent dampers, power burners, zoning, and temperature setback. For boilers, options include boiler water temperature reduction, jacket insulation, and economizers. Pipe and duct insulation is appropriate for all types of systems when it is practical. Also, new high efficiency equipment is appropriate at time of replacement.

Class II consists of mid-sized commercial buildings with heating equipment in the range of 300,000 to $2,000,000$ Btu per hour. This equipment is generally not fully modulating, but may have high-low firing capability. This size class is not as well-defined and more research is needed to characterize equipment design and efficiency, and to identify and evaluate general energy conservation options. It is an important size class, however, because of the number of buildings that are included and the large gas savings that can be achieved. Based on equipment average sizes, it is possible that most of the boilers (steam and hot water) and some of the furnaces in LILCO's commercial buildings are in this category.

Some of the options listed for Class I equipment are appropriate for Class II, but the most that can be said is that many options may be applicable for this size range, depending on the specific equipment in the building. For example, some of the buildings in this size class may be large enough to warrant an Energy Management Control System but in smaller buildings separate controls may be more appropriate. Gas burner replacement may also be appropriate, but more research is needed to characterize the performance of existing gas burners in this size range. The costs given in the Table are generally for Class I equipment, and are likely to be higher for Class II.

Class III consists of large commercial buildings with heating equipment that is above $2,000,000$ Btu per hour. This equipment is likely to be fully modulating. This category includes schools, hospitals, large office buildings, and other large structures for which significant information exists based on past energy conservation studies. The energy cost savings in these buildings is sufficient to justify individual energy surveys, energy use analyses, and custom engineering design of energy conservation projects for each building in this size class. Some additional engineering research is recommended to identify key energy conservation options and analysis procedures, and to develop training material for use in these buildings.

These large buildings probably represent about 40 percent of the commercial floorspace and about the same percent of gas use in LILCO's service territory. It is likely that most of the heating equipment in this size class is boilers.

Class III options include ventilation air control, temperature reduction (during occupied and unoccupied hours), and boiler plant improvements. These three areas have been proven to produce the highest fuel savings with the best payback periods. In large buildings, ventilation 
air control and temperature control are generally handled by Energy Management Systems. Boiler Plant Optimization is a general term that applies to a number of options that can improve the operating efficiency of boiler plants in commercial buildings. These boiler plants often include multiple steam or hot water boilers and ancillary equipment, and the optimization options may include automatic boiler selection, boiler isolation, outdoor air boiler lockout, boiler water temperature control, combustion efficiency monitoring, and condensate return monitoring.

Hundreds of other low cost and capital intensive conservation options are available (including building envelope upgrades and maintenance programs), that could be added to these primary options to develop a specific energy conservation program for each specific Class III building. This requires more information on the specific energy use of each building, which must be determined by a building energy survey and engineering analysis of each building.

No attempt is made here to derive total potential savings estimates for LILCO's commercial sector. More information is needed on existing buildings and equipment in order to determine savings that may be obtained from each measure. Critical information includes the firing rate and efficiencies of existing equipment, the size distribution of the equipment, the number of multiple boiler sites, and the non-heating demands being met by the equipment. Important building information includes square footage, use, and operating hours.

In addition, shell and other HVAC measures need to be considered. Often more than one measure will be cost-effective for a given installation. It would not be accurate to simply sum the expected savings from multiple measures, because measures interact with other, often in complex and unexpected ways. This is discussed briefly in the following section.

\section{Measure Interactions}

It is difficult to estimate savings from a single conservation measure because performance depends on the characteristics of the building, existing systems, the quality of installation, and operation and maintenance skills. It is more difficult to estimate savings when more than one measure is installed. Combustion and HVAC equipment are part of complex systems that interact not only with each other but also with the building shell.

Interactive effects between lighting systems and cooling have probably received the most study. Improving lighting efficiency, by replacing incandescents with fluorescents, for example, increases heating load and reduces cooling load. The efficiency of a lighting system is also affected by the temperature at which it operates. Current research is exploring these interactions in detail, with the goal of optimizing lighting and HVAC system performance (Treado and Bean).

Much less is known about other types of interactions. Temperature setback is generally considered one of the most cost-effective ways to save energy, depending on the operating hours of the business. One study which simulated interactions among shell measures and 
temperature setback in a small single-story commercial building showed significant reductions in savings from temperature setback depending on the amount of ceiling insulation (Sharp and MacDonald, 1992). Wall insulation generated less energy savings than ceiling insulation, but increased the savings from ceiling insulation.

The complexity of potential interactions necessitates a rigorous approach to estimating savings potentials. Simulation models may capture many of them, but when multiple measures are installed, it may be necessary to validate and verify savings estimates with monitored data. One such project (Cleary and Schuldt) found stronger than expected interactions between refrigeration, lighting, and heating in a grocery store. Actual total savings were greater than predicted. Determining cost-effectiveness also becomes more complex. A combination of simulation and selected building monitoring can increase confidence in savings estimates.

Further exploration of interactions was beyond the scope of this effort. A systematic literature search, combined with personal contacts, would provide a first step in determining whether reasunable assumptions can be made about measure interactions in specific building types, and would determine where further research is necessary.

\section{DISCUSSION}

It is important to characterize existing buildings and equipment in order to have confidence in gas DSM program design and savings estimates. The tremendous range in building and equipment sizes in the commercial sector makes it particularly difficult to define a standard set of appropriate conservation measures. Energy use, and savings potential, are greatly influenced by building use, particularly the hours of operation.

The commercial sector is sufficiently complex and diverse that generalizations are difficult to make. Interactions among measures further complicate the process. There is a tremendous difference between large and small buildings, and the associated equipment, that these segments need to be addressed differently. Very little is known about mid-size buildings and equipment.

Large buildings are less dependent on weather, and often require cooling all year. Energy system performance is complex and unique to each building. Large buildings must be evaluated individually, using well-trained contractors with a thorough understanding of the equipment and possible interactions. In addition, large customers may have complex rate structures which need to be factored into the analysis.

Small buildings, on the other hand, are more likely to act like residential buildings and to have residential-size equipment. The lessons learned in large buildings are not transferrable to small buildings. Experience in the residential sector may be applicable, however.

Other issues which are likely to be important in implementing gas DSM programs were beyond the scope of this study. It did not address the difficulties in reaching the commercial sector, especially the small businesses, in order to actually achieve the savings that are 
possible. Different approaches may be necessary for tenant-occupied facilities than for owner-occupied buildings. Lessons learned from electric DSM programs may be applicable.

Finally, there are other factors which affect savings and the persistence of savings from conservation measures. If measures are not installed properly by qualified contractors, or if local contractors are unfamiliar with the new equipment, savings will not be achieved or will not persist. Heating and control equipment can be complex, and contractor training may need to be a significant part of a successful gas DSM program. Changes in operation may hide savings. If equipment is too compiicated or not easily integrated with normal operations, customers will stop using it. Ongoing maintenance is also a factor in the long-term persistence of savings; training or incentives may be appropriate.

\section{RECOMMENDATIONS}

LILCO needs to learn more about its commercial buildings and the existing gas-fired equipment. The importance of developing a broader understanding of the commercial sector cannot be overstated. It is recommended that LILCO pursue a systematic approach to developing reliable estimates of important building and equipment characteristics. In order to estimate conservation potential, it is necessary to know the age and efficiencies of existing equipment, its size distribution, the number of multi-boiler installations, and how non-heating demands are met. Building use data, including hours of operation, are also needed to estimate savings potential, as well as information about building shell characteristics, distribution systems, and other gas-fired equipment.

It is likely that much of the necessary data is available to LILCO from existing data sets. A concerted effort to consolidate existing data is recommended.

Continued efforts to improve the data gathered from audits and to determine the usefulness of the audit database for characterizing the commercial sector are encouraged. The simplest approach would be for LILCO to obtain all the data from selected years from the database. This would provide the greatest flexibility in determining the usefulness of existing data. This would allow LILCO to develop a snapshot characterization of its commercial sector for current analyses and to define standard reports for the future as the database is expanded. Characterization by building would be useful in comparisons with other available data.

The use of billing data, possibly in conjunction with the audit database, should also be explored. Billing data may provide a relatively simple way to categorize gas customers by business type, size and gas use. This would help identify those subsectors or customers who would benefit most from conservation efforts.

A survey of the commercial sector could also be considered. If the audit database shows significant gaps in important areas or if analyses of billing data identify particularly important subsectors, a selective survey of segments of the 
commercial market could provide missing information. The survey could collect both equipment and non-equipment data. In the interim, or if LILCOspecific data are not obtainable, other data sources such as CBECS may be useful.

It is also important that LILCO continue to develop a greater understanding of the savings and costs of conservation measures, especially in the middle size range of buildings and equipment.

A systematic literature search, combined with a preliminary characterization of its commercial sector, would help LILCO select and prioritize combinations of measures to be evaluated.

A workshop of local energy service company representatives could provide useful practical information on what measures have been tried in L.ILCO's service territory. Practitioners will be familiar with local buildings and be knowledgeable about what works in the field. Gaps in practical experience would also be identified.

Pilot programs and field monitoring and/or simulations should be carefully structured to provide information that will ve useful in full-scale and future program design. These activities are expensive and time-consuming, and should not duplicate other efforts. Care should be taken to select measures and combinations of measures for each building type or size that have wide applicability. The target populations and measures should be selected so that results can be confidently extrapolated to larger populations.

If LILCO needs to proceed quickly with gas conservation programs, it is likely that the most cost-effective approach would be to select a few large customers and design custom programs for them. Large buildings must be evaluated individually anyway, and it is a reasonable assumption that more savings could be obtained from large gas users. If costs and savings are documented, estimates of savings for future programs could be made with greater confidence.

For equity reasons, it is also recommended that LILCO select several types of small customers for pilot programs. A preliminary categorization, possibly using billing data or audit results, could be used initially to select segments of the population. Monitoring should be included in these pilot programs to document both costs and savings. A carefully designed set of pilot programs, especially those which consider measure interactions, would provide valuable information to the buildings energy research community and other utilities, as well as to LILCO staff. 


\section{REFERENCES}

Andrews, J.W., R.J. McDonald, R.F. Krajewski, L.M. Woodworth and J.E. Batey. Triage of Oil and Gas Retrofits for Residential/Light Commercial Heating Systems, BNL-38090, Brookhaven National Laboratory, Upton, New York. May 1986.

Batey, J.E. "Technical Assistance Energy Study for the Parker Jewish Geriatric Institute," Facility Energy Services, Inc. July 1990.

Batey, J.E. "Energy Balance Study and Recommended Energy Conservation Projects for Eight Facilities Operated by the New York State Facilities Development Corporation," Facility Energy Services, Inc. 1986.

Batey, J.E. Energy Management in Residential and Small Commercial Buildings, BNL-50576, Brookhaven National Laboratory, Upton, New York. July 1976.

Berlad, A.L., H.C. Lin, J. Batey, F.J. Salzano, W.S. Yu, R.J. Hoppe, and T. Allen. Seasonal Performance and Energy Costs of Oil or Gas-Fired Boilers and Furnaces, BNL-50647, Brookhaven National Laboratory, Upton, New York. March 1977.

Briggs, R.S. "Categorizing the Builuing Stock for Energy Studies: Using Survey Data and Statistical Methods to Define Effective Categories," ASHRAE Transactions, V. 96, Pt. 1. 1990.

Cleary, C.M. and M.A. Schuldt. "Predicted vs. Actual Conservation Opportunities in Commercial Buildings: Lessons Learned from Measured Energy Performance," ASHRAE Transactions, V. 95, Pt. 2, 1989.

Crawley, D.B. and Y.J. Huang. "Using the Office Building and Multifamily Data Bases in the Assessment of HVAC Equipment Performance," ASHRAE Transactions, V. 95, Pt. 2, 1989.

Goldner, Fredric S. "BEUTS Final Report," Energy Conservation Division, Department of Housing Preservation and Development, New York, New York. December 1989.

Hampton Strategies, Inc. Estimate of the Potential for Natural Gas Utility DSM Programs on Long Island, Revised Draft Report, Hampton Strategies, Inc., Hauppauge, New York. July 1992.

Hill, Douglas and Miriam Kroon. "Long Island Energy Plan--Final Draft," prepared for the Long Island Regional Planning Board. 1991.

Huang, Joe, Hashem Akbari, Leo Rainer, and Ron Ritschard. 481 Prototypical Commercial Buildings for 20 Urban Market Areas, GRI-90/0326, LBL-29798, Lawrence Berkeley Laboratory, Berkeley, California. April 1991. 
MacDonald. J.M., T.R. Sharp and M.B. Gettings. A Protocol for Monitoring Energy Efficiency Improvements in Commercial and Related Buildings, ORNL/CON-291, Oak Ridge National Laboratory, Oak Ridge, Tennessee. September 1989.

Nadel, Steven, Joseph Eto, Mark Kelly, and Jennifer Jordan. Gas DSM and Fuel-Switching: Opportunities and Experiences, Draft, American Council for and Energy-Efficient Economy, Washington, D.C. 1992.

Putnam, A.A., S.G. Talbert, R.D. Vergara and A. Levy. Survey of Available Technology for the Improvement of Gas-Fired Residential Heating Equipment, BNL-51067, Brookhaven National Laboratory, Upton, New York. August 1979.

Sharp, T.R. and J.M. MacDonald. Measurement of Energy Performance in a Small Bank Building, ORNL/CON-297, Oak Ridge National Laboratory, Oak Ridge, Tennessee. April 1990.

Sharp, T.R. and J.M. MacDonald. "Energy Savings and Interactions from Retrofit Measures in Small Commercial Buildings in Boston," Thermal Performance of the Exterior Envelopes of Buildings V, Proceedings of the ASHRAE/DOE/BTECC Conference, Clearwater Beach, Florida. December 7-10, 1992.

Stucky, D.J. and D.B. Belzer. "Review of Prototypical Buildings Used for Commercial Sector Energy Analysis," Letter Report, Pacific Northwest Laboratory, Richland, Washington. December 1992.

Treado, Stephen J. and John W. Bean. Measurement and Evaluation of Lighting/HVAC Interaction, NISTIR 4429, National Institute of Standards and Technology, U.S. Department of Commerce, Gaithersburg, Maryland. May 1991.

XENERGY, INC. "Equipment Inventory Reports for the L!LCO Service Territory," XENERGY, INC., Burlington, Massachusetts. February 1990. 


\section{APPENDIX A. CONSERVATION MEASURE DESCRIPTIONS}

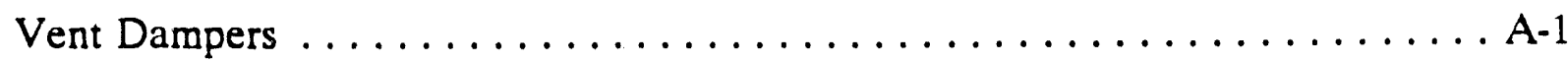

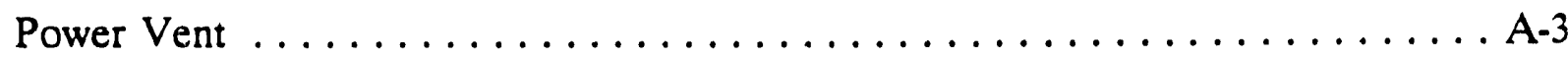

Electric Ignition $\ldots \ldots \ldots \ldots \ldots \ldots \ldots \ldots \ldots \ldots \ldots \ldots \ldots \ldots \ldots \ldots \ldots \ldots$

Boiler Water Temperature Reduction $\ldots \ldots \ldots \ldots \ldots \ldots \ldots \ldots \ldots$ A-5

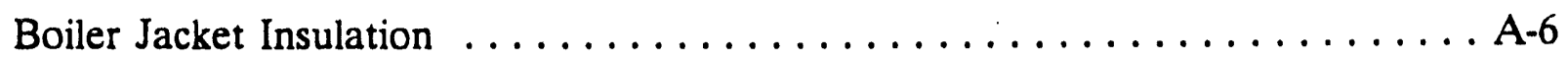

Economizer - Boiler $\ldots \ldots \ldots \ldots \ldots \ldots \ldots \ldots \ldots \ldots \ldots \ldots \ldots \ldots \ldots \ldots \ldots \ldots$

Pipe/Duct Insulation $\ldots \ldots \ldots \ldots \ldots \ldots \ldots \ldots \ldots \ldots \ldots \ldots \ldots \ldots \ldots \ldots \ldots$

Power Burners $\ldots \ldots \ldots \ldots \ldots \ldots \ldots \ldots \ldots \ldots \ldots \ldots \ldots \ldots \ldots \ldots \ldots$

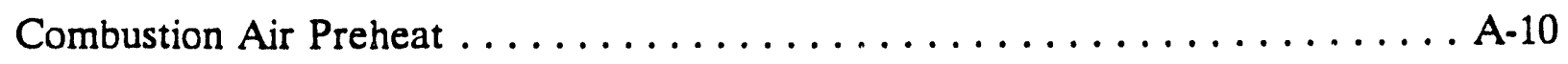

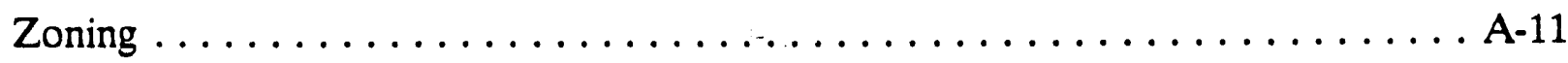

Automatic Setback Thermostat $\ldots \ldots \ldots \ldots \ldots \ldots \ldots \ldots \ldots \ldots \ldots$ A 12

High Efficiency Boiler/Furnace $\ldots \ldots \ldots \ldots \ldots \ldots \ldots \ldots \ldots \ldots \ldots \ldots \ldots \ldots \ldots$

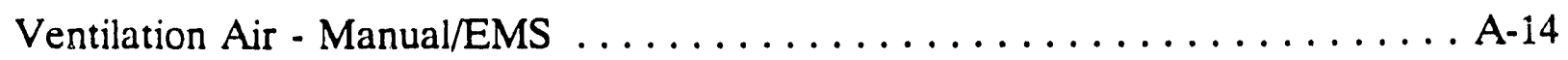

Building Temperature Control - EMS $\ldots \ldots \ldots \ldots \ldots \ldots \ldots \ldots \ldots \ldots$ A-15

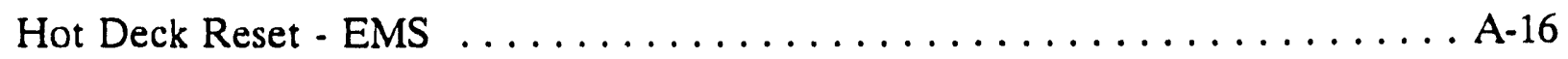

Burner Efficiency Adjustment $\ldots \ldots \ldots \ldots \ldots \ldots \ldots \ldots \ldots \ldots \ldots \ldots \ldots \ldots \ldots$

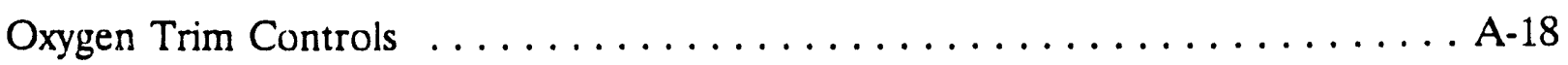

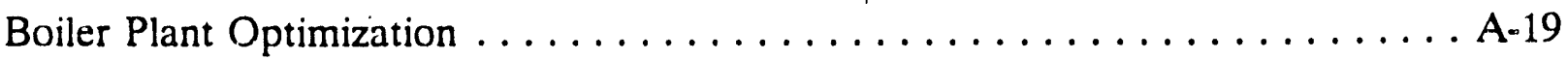

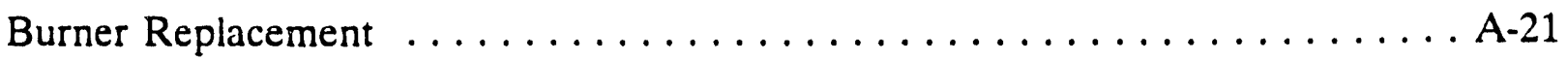

Boiler Replacement (Partial) $\ldots \ldots \ldots \ldots \ldots \ldots \ldots \ldots \ldots \ldots \ldots \ldots \ldots \ldots \ldots \ldots \ldots \ldots$

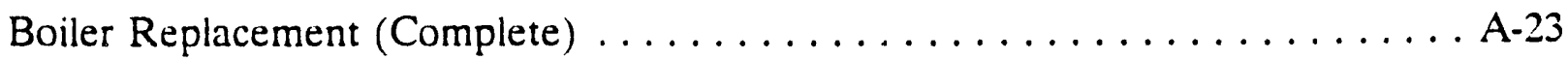




\section{REFIT OPTION: VENT DAMPER}

\section{TECHNICAL DESCRIPTION:}

The principle behind the vent damper is quite simple. In residential heating equipment, heat stored in the boiler or furnace can be lost during the burner off-cycle. This is a result of the lingering buoyancy effect that exists within the heating system which includes the equipment heat exchanger, flue pipe and chimney. As long as the heat exchanger remains hot there will be a driving force expelling hot gases from the system. This hot gas is made up of cooi air drawn in through the burner combustion air inlet, which cools the heat exchanger and leaves the system via the chimney. this process continues until there is no temperature difference between the heating equipment and the outside air. If the equipment is located in a conditioned space, this loss removes warm air from the conditioned space increasing air infiltration into the building. Vent dampers are designed to shut off the flue gas venting process after burner shutdown, thereby eliminating the aspiration of cool air through the system. Vent dampers can be broken down into three classifications:

1. Electrical - This type uses an electric motor to operate the butterfly (rotating disc) valve within the flue pipe. these u nits, when used on oil-fired systems, often contain time delays which allow the combustion product gases to escape before they fully close. If there is no time delay, knockouts are sometimes provided in the butterfly valve to let the remaining combustion gases escape. This type of design (continuous bypass) is less efficient. For gas system applications with pilot burners, an opening in butterfly valve is always required to vent exhaust gases.

2. Mechanical - This type of vent damper usually works off gas pressure which mechanically opens and closes the vents in the flue pipe. this type is not as common as the electrical type for retrofitting because it takes more time to install. This type of system does not incorporate a time delay and uses knockouts for combustion bypass.

3. Bimetallic - This type of damper is a circular bimetallic element which is driven open by the rising flue gas temperature when the burner starts. It is the least efficient unit since it must have sufficient openings (cross-sectional) to accommodate light-off before opening. However, it is also the cheapest and easiest to install.

\section{ADVANTAGES:}

The savings potential of vent dampers varies with the design of the particular unit. Laboratory tests have indicated that continuous bypass designs suffer substantially in terms of savings potential when compared with the time delayed closure damper with no bypass. The tests revealed that the savings for a time delayed damper with no bypass was about $11 \%$ 
on a particular boiler, while only a $5 \%$ savings could be achieved when a continuous bypass design was used. the bimetallic units are expected to produce less than $5 \%$ savings.

The opportunities for savings in furnaces is not fully documer.ied but appears to be about $5 \%$. This lower savings figure is due largely to the lower thermal storage capacity of furnace heat exchangers and the fact that furnaces do not standby at elevated temperatures as do boilers.

The savings potential for gas applications using vent dampers may be greater than the $11 \%$ icientified $\mathrm{fc}_{i}$ oil boilers and the $5 \%$ for oil furnaces. This greater potential is due to the larger off-cycle air flow through gas atmospheric burners used in most gas boilers and furnaces, and the greater off-cycle loss ior this equipment.

These figures do not take into account the additive savings effects due to the potential reduction of exfiltrated air from the heated space. This latter area of savings potential is a subject of some considerable research even now.

\section{DISADVANTAGES:}

Requires removal and modification of vent pipes and proper installation by specially trained service technicians to assure safe operation of the heating system.

\section{NEED FOR FURTHER RESEARCH:}

Develop better understanding of building/heating unit interactions to improve predictions of fuel savings. These studies could also help to develop recommended guidelines for optimal combinations of retrofit options. Presently, this information does not exist. Further research is also necessary to determine the applicability of vent dampers to mid-size heating systems. 


\section{REFIT OPTION: POWER VENT}

\section{TECHNICAL DESCRIPTION:}

Power venting uses a small electric motor connected to an induced draft fan to pull the combustion gases through the burner rnd heat exchanger into the exhaust pipe. A chimney is not required because the negative pressure required to remove the combustion gases is supplied by the fan. This improves efficiency through better control of the combustion air supply and through elimination of the draft hood. Off-cycle heat losses are also reduced by eliminating the chimney and its off-cycle heat losses. Power venting is a feature now incorporated into high efficiency gas heating units because the flue gas temperatures are too low for natural draft venting through a chimney. Design guidelines are needed so that power venting can become a viable retrofit option. Installation procedures are needed that insure adequate combustion air to avoid production of hazardous combustion gases. Also, code restrictions that prevent power vent retrofits must be identified and changed.

\section{ADVANTAGES:}

The use of induced draft venting systems can improve both steady state and seasonal efficiency of a unit because it controls secondary air flow during combustion and reduces natural drafting during the off cycle.

\section{DISADVANTAGES:}

uses more electrical power. Retrofit applications must be carefully monitored to prevent unsafe venting conditions through improper design or failure of the induced $d$ raft fan.

\section{NEED FOR FURTHER RESEARCH:}

- Standardized design and installation procedures are needed.

- Field studies are needed to demonstrate the fuel savings for a wide range of gas heating system applications. 


\section{REFIT OPTIONS: ELECTRIC IGNITION (IID AND DSI)}

\section{TECHNICAL DESCRIPTION:}

The replacement of a standing pilot ignition system with an electronic Intermittent Ignition Device (IID) or an Interrupted Ignition System (Direct Spark Ignition or DSI) has long been an option to reduce gas consumption in boilers and furnaces. The DSI system utilizes an electronic module to monitor and ignite the burner directly with a high voltage spark which is de-energized once ignition has been verified by the control module. The IID uses an electronic module to ignite a standing pilot which in turn ignites the main burner. The pilot remains lighted and is extinguished only when the call for heat is satisfied. These systems have potential for significant energy savings, but can add a significant cost factor to the appliance. No research is required, as manufacturers are well aware of the potential energy savings and additional costs in using this technology. The actual savings are directly related to the pilot gas consumption rate and the cycling rate off periods which exhibit pilot losses.

\section{ADVANTAGES:}

Energy savings of $4.4 \%$ have been reported. Greater savings apply if central air conditioning is used at the same time as a constantly burning pilot is operating.

\section{DISADVANTAGES:}

There are no significant savings in replacing the pilot if the pilot is turned off for the nonheating season. Installation can lead to severe safety problems unless done by qualified personnel. 


\section{REFIT OPTION: BOILER WATER TEMPERATURE REDUCTION}

\section{TECHNICAL DESCRIPTION:}

Lowering the average boiler temperature is a modification that saves fuel without a loss of comfort level. Less heat is stored in a heating unit when the temperature is reduced, and off cycle heat loss decreases. For example, hot water boilers are often set to supp'y water at $200^{\circ} \mathrm{F}$. In many cases the aquastat (temperature control) can be reduced to $: 80^{\circ} \mathrm{F}$ in winter and $140^{\circ} \mathrm{F}$ in summer for domestic hot water usage.

This can be obtained in two ways, manual adjustments or automatic adjustment using a retrofitted control package with sensors to detect outside temperature, boiler water temperature, and room temperature. The boiler temperature is controlled by the water temperature controller through burner control (on-off) based on the various inputs.

Laboratory tests on a hydronic boiler have shown a direct relationship between boiler temperature and off-cycle loss. Off-cycle heat loss doubled when the boiler water temperature was increased from $140^{\circ} \mathrm{F}$ to $200^{\circ} \mathrm{F}$.

The savings projected with this operation mode range from $5 \%$ to $12 \%$ in annual fuel consumption based on initial levels of efficiency and the degree of boiler water temperature modulation which is used in each case. The costs range from $\$ 0$ for the case of manual adjustment (seasonal), to $\$ 350$ or more for fully automatic programmable controls installed on the boiler system.

\section{ADVANTAGES:}

Reduces off-period losses. Energy savings of up to $12 \%$ have been reported. Manual reset is a simple adjustment. In buildings with too few radiators, the boiler output is excessive and the boiler cycles on the high limit control, wasting energy. If it is possible, the number of radiators should be increased. If this is not possible, reducing the boiler water temperature would reduce short cycling.

\section{DISADVANTAGES:}

The most effective type (automatic reset control) is expensive. Boiler temperature reduction must be applied carefully when a domestic water heating coil is used. Reducing water temperature too much could cause excessive condensation on heat up on the flue gas side and reduce boiler life. The optimum reset schedule for the boiler water may vary from building to building and must be customized for best results. 


\section{REFIT OPTION: BOILER JACKET INSUI.ATION}

\section{TECHNICAL DESCRIPTION:}

This option entails the addition of blanket insulation around the body of a boiler or furnace in order to retard heat loss. Such insulation is effective if the unit is located in an unheated space.

\section{ADVANTAGES:}

Easy to install.

Very effective for boilers

\section{DISADVANTAGES:}

Less effective for furnaces that have minimal heat storage. Installer must be careful not to restrict the flow of combustion air to the burner. Some boilers and furnaces operate with low jacket heat losses. 


\section{REFIT OPTION: ECONOMIZERS}

\section{TECHNICAL DESCRIPTION:}

Waste heat recovery devices have been shown to be effective in saving between 9 to 20 percent depending on the condition of the heating system or subsequent temperature of the flue gas. Units that are designed for hydronic systems reclaim energy from the departing combustion gases by pumping water that is returning to the boiler through a separate heat exchanger placed in the flue. This recovered heat is carried back to the boiler and available for delivery to the heating space. Air-to-air heat reclaimers transfer heat from the hot flue gases to local room air in the vicinity of the heating unit. The thermal performance of these economizers depends greatly on the temperature of the flue gas entering the economizer and the degree to which the economizer heat exchanger tends to foul with soot or scale.

Heat recovery that forces the flue gas to condense and captures the latent heat of vaporization can provide steady state efficiencies up to 95 percent.

\section{ADVANTAGES:}

Will recover significant waste heat from the flue gases of inefficient heating units.

\section{DISADVANTAGES:}

In non-condensing environments, care must be taken to avoid lowering the exhaust gas temperature too much, causing condensation in the economizer or chimney.

For condensing economizers, corrosion of the heat exchange surfaces may occur. 


\section{REFIT OPTION: DUCT AND PIPE INSULATION}

\section{TECHNICAL DESCRIPTION:}

Warm air ducts and hot water pipes often waste large amounts of energy when they are not properly sealed and insulated. These avoidable heat losses reduce system efficiency and increase fuel use. Warm air ducts can lose heat in two ways. First, leaks at duct joints can permit the heated furnace air to be lost to unheated parts of the building (attics, crawl spaces and basements) before reaching the room air diffusers. This loss can be as high as 40 percent in extreme cases. Secondly, that loss can occur through the duct walls when uninsulated ductwork passes through unheated parts of the building.

Pipe heat loss also occurs as hot water or steam is distributed to radiators in the building through uninsulated piping passing through unheated areas of the building. The size of the heat loss depends on: the temperature of the hot water or steam, the diameter and length of piping, degree of thermal insulation and the temperature of the cold air surrounding the pipe. These conditions change from building to building but heat losses in the range of 10 percent are possible. Additional pipe heat losses can occur during on-off cycling of hydronic heating systems. The water contained within the pipes when the water circulator is off continues to lose heat to the cold surrounding air. Calculations indicate that approximately $215 \%$ of the boilers heat output can be lost to off-cycle pipe heat losses during the mild parts of the heating season with long off periods. Again, the size of this heat loss varies widely depending on the design of the piping system. The total pipe heat loss is the sum of on-cycle and off-cycle losses averaged over the entire heating season.

All warm air duct joints must be completely sealed, and all warm air ducts and hot water pipes that pass through unheated building areas must be completely covered with thermal insulation to prevent unnecessary fuel consumption.

\section{ADVANTAGES:}

Improved warm air duct and hot water pipe sealing and insulation can reduce fuel consumption and increase the useful heat delivered to the heated areas of the building. The cost for these improvements is usually small when compared to the savings.

\section{DISADVANTAGES:}

Some "unheated" part of the building such as basements may become colder after the distribution heat losses are reduced. This problem can be overcome by installing a supply air register(s) or radiator in the basement that can be closed when the space is unoccupied. 


\section{REFIT OPTION: POWER GAS BURNER}

\section{TECHNICAL DESCRIPTION:}

A power gas burner uses an electric-powered forced draft blower to provide combustion air for burning the gaseous fuel. In most commercialized designs for these burners, the fuel gas and air are kept separate and only mixed in the combustion zone. There has been some work done in what are called premixed burners where the fuel gas and combustion air are mixed ahead of the blower and the mixture is then blown into the combustion zone. There is one such burner on the market and it is available in two models covering a wide range of firing rates.

\section{ADVANTAGES:}

In some cases power burners may be used to replace atmospheric gas burners that are very inefficient by design because of poor control of fuel-air ratio and excessive off-cycle heat losses.

\section{DISADVANTAGES:}

The performance of two power gas burners have been evaluated at BNL and the results show moderately good performance is achievable but slightly below that expected from a high performance oil burner in the same heating unit. Also, it is difficult to replace atmospheric gas burners with power gas burners because they are configured differently.

\section{NEED FOR FURTHER RESEARCH:}

Further evaluation in different heat exchangers may be required to completely characterize the performance of the power gas burner as a retrofit option. Emphasis should be placed on replacing the existing atmospheric gas burners with power burners to improve the efficiency of existing gas-fired heating systems where possible. 


\section{REFIT OPTION: COMBUSTION AIR PREHEATING}

\section{TECHNICAL DESCRIPTION:}

Combustion air preheating is commonly used in large commercial and industrial applications. Hot gas economizers are used to extract heat from flue gases issuing from large boilers, furnaces, kilns and ovens for preheating combustion air before it enters the burner. In commercial applications the exiting flue gas temperature entering economizers may exceed $1000^{\circ} \mathrm{F}$ and preheated air temperatures can exceed $600^{\circ} \mathrm{F}$. The fuel savings potential under these circumstances will be approximately $14 \%$ or greater for gas-fired equipment.

For small commercial space heating equipment the savings potential is less because both the available flue gas temperatures and permissible combustion air temperatures are much lower. For typical low efficiency heating equipment found in the field, the exiting flue temperatures may be as high as $600^{\circ} \mathrm{F}$.

\section{ADVANTAGES:}

If it were possible to heat the combustion air to about $200^{\circ} \mathrm{F}$ without negative effects, the potential savings could be as high as $8 \%$.

\section{DISADVANTAGES:}

The permissible air temperature for combustion air preheating in residential applications should be less than that which would permit fuel handling parts from reaching $120^{\circ} \mathrm{F}$ for safety when using conventional residential burner equipment and controls. Furthermore, advanced combustion air controls may be needed to compensate for changes in air density at elevated temperatures. Finally, the elevated flame temperatures produced may not be compatible with conventional combustion chamber materials. 


\section{REFIT OPTION: ZONING}

\section{TECHNICAL DESCRIPTION:}

Dividing a building into two or more separate zones that can be heated to different temperatures, in the comfort zone when occupied, and at lower temperatures when the space is unoccupied, can result in $30 \%$ reduction in space heating demand if the cool zone is deeply set back to $50^{\circ} \mathrm{F}$. Achieving such zoning is relatively easy for hydronic systems because independent loops can be created by breaking into the existing single loop and by installing additional circulators and thermostats. Alternatively, zoning with a single loop may be possible if a low-flow-rate circulator is used in conjunction with a reversing valve. This latter strategy has been studies theoretically but needs to be validated experimentally.

For forced-air systems, zoning is more difficult because of problems with duct balancing, excessive duct leakage, and noise when part of the system is shut down. For new construction, forced-air zoning is a subject for research. For retrofit, it is sufficiently problematic as to be an unlikely option for years to come.

\section{NEED FOR FURTHER RESEARCH:}

Research is needed into means for cost-effective zoning on a retrofit basis. This would not only mean technology options for hydronic and forced-air systems, but would include a survey of buildings to assess applicability of various options. 


\section{REFIT OPTION: THERMOSTAT SETBACK}

\section{TECHNICAL DESCRIPTION:}

Thermostat setback is a proven method of energy conservation. Setback can be either permanent, in which case occupants live with colder indoor temperatures day and night, or time-of-day, in which case colder temperatures occur only during sleep periods or times when the building is unoccupied. In a typical 6000 degree-day climate, a $5^{\circ} \mathrm{F}$ night setback (for $8 \mathrm{hr}$ ) will reduce the annual space heating load by $8 \%$. If combustion space heating equipment is used, there is generally little problem with capacity required to rewarm the building in the morning, since these units are generally oversized. Overall efficiency will probably not change much.

\section{ADVANTAGES:}

- $\quad$ Significant energy savings

- Low cost

- Little or no discomfort with time-of-day setback

\section{DISADVANTAGES:}

- Possible discomfort if permanent setback is used, particularly if the building has elderly occupants who are most sensitive to lower space temperatures.

- Savings are reduced if building is continually occupied.

- Many people already set back the space temperature manually, and this will reduce the potential energy savings. 


\section{REFIT OPTION: HIGH EFFICIENCY BOILER/FURNACE}

\section{APPLICATIONS: Small Commercial}

\section{TECHNICAL DESCRIPTION:}

Replacing an older gas-fired heating system with a new, energy efficient furnace or boiler involves a substantial initial expenditure that pays off over the long term with yearly energy cost savings, lower maintenance expenses, and improved reliability. The cost-effectiveness of buying a new unit depends on: (1) the existing furnace or boiler condition and efficiency; (2) the new equipment efficiency, initial cost, and anticipated maintenance cost; and (3) present annual heating costs. Typical fuel savings for small commercial buildings are 20 to 40 percent.

The Federal Trade Commission requires that all new residential furnaces and boilers below 300,000 Btu per hour be tested and given an Annual Fuel Utilization Efficiency (AFUE) rating. The AFUE efficiency is a measure of seasonal or annual efficiency of a furnace or boiler. It takes into account the cyclic on/off operation and associated energy losses of the heating unit as it responds to changes in the load, which in turn is affected by changes in weather and occupant controls. AFUE rating is very important when selecting a new heating system. 


\section{REFIT OPTION: VENTILATION AIR}

APPLICATIONS: Larger Commercial Buildings with HVAC Systems

\section{TECHNICAL DESCRIPTION:}

One function of HVAC equipment is to introduce outdoor air into the building for ventilation. However, this cold outdoor air represents a significant heat load since it must be heated to the indoor temperature. Minimizing the volume of outdoor air is an important energy conservation opportunity in many buildings. In some commercial buildings (typically in size class II or III), manual adjustment of outdoor air dampers and reduction of exhaust fan flow rates can reduce excessive ventilation rates and the associated excessive energy use.

In larger commercial buildings with more complicated HVAC systems, more sophisticated automatic ventilation control using an electronic or computerized Energy Management System is often recommended. The following ventilation operations are often applied:

- The outdoor air dampers (and exhaust dampers) are closed whenever the building is unoccupied to lower energy use.

- The position of outdoor air dampers (and exhaust dampers) is controlled when the building is occupied to reduce the volume flow rate of ventilation air to minimum values needed to maintain satisfactory indoor air quality.

- If night temperature setback is used, the outdoor air dampers are closed during the morning warm-up cycle to reduce the peak heating demand (and energy use) imposed on the heating equipment.

Commercial building energy studies have found that ventilation air can be a significant fraction of the heating energy use ranging from $10 \%$ to more than $50 \%$ of the total demand. Therefore, the reduction of ventilation air by simply adjusting the position of outdoor air dampers, or by control through an Energy Management System, can be an important energy conservation option that produces excellent paybacks of 1 to 2 years in many cases.

In buildings of size class III, such as schools and hospitals, detailed engineering studies are recommended to evaluate the level of ventilation air that exists and to determine the level of reduction that is recommended without negatively affecting the quality of the indoor air. More research is needed for mid-sized commercial buildings to develop generalized recommendations for optimum control of ventilation air flow rates to save energy. 


\section{REFIT OPTION: BUILDING TEMPERATURE CONTROL}

\section{APPLICATIONS: Commercial Buildings of All Sizes}

\section{TECHNICAL DESCRIPTION:}

Temperature controls include reducing the temperature during occupied hours, and allowing night temperature setback during unoccupied hours to lower the energy used for space heating. In small commercial buildings, programmable thermostats are often adequate for this purpose. In large commercial buildings temperature control often requires adjustment to local zone controls (of HVAC equipment) supervised by an Energy Management System. The EMS offers many important advantages

- Accurate scheduling of building occupancy times so that maximum setback is achieved.

- Control of all heating and ventilating units serving each zone of the building for better temperature reduction.

- Reduced cost of temperature sensors by monitoring representative building zones to maintain minimum night temperatures.

- Adaptive control that allows the morning start-up time to vary based on outdoor air temperature and building mass and heat losses.

The EMS-based temperature controls are frequently recommended for large commercial building in size class III after an energy study is completed. Energy savings of $5 \%$ to $30 \%$ or more are often possible in these buildings. More research is needed to characterize size II so that general recommendations can be developed for this type of commercial building. 


\section{REFIT OPTION: HOT DECK RESET}

APPLICATIONS: Commercial Buildings HVAC Systems with Reheat

\section{TECHNICAL DESCRIPTION:}

Some HVAC equipment used in commerciai buildings sich as dual duct and multizone designs use hot and cold air supplies that are mixed at each zone to produce the desired air temperature. This is inefficient and increases energy use during the heating season by overheating the air supply and then cooling it in each building zone. In some cases the hot deck (hot air supply) temperature can be reset to a lower value to reduce the amount of cool outdoor air that is mixed with the hot air. This reduces the amount of energy used by the heating plant in the building. This hot deck reset function can be included in Energy Management Systems that measure the hot deck temperature of each building zone and then reduce the supply air temperaiure from the HVAC unit to the lowest temperature possible for all zones. The actual savings vary depending on the design of the HVAC system and building heat losses, but this option can significantly reduce energy use by inefficient HVAC systems at a reasonable added cost if an EMS is installed.

This option can be used in large commercial building in size class III, but may be applicable to smaller buildings also, if the building HVAC systems is upgraded with some form of central control. More research is needed to evaluate the typical costs and savings produced by this option for mid-siz. $d$ buildings. 


\section{REFIT OPTION: GAS BURNER EFFICIENCY ADJUSTMENT}

APPLICATIONS: Commercial Buildings with Gas-Fired Heating Equipment

\section{TECHNICAL DESCRIPTION:}

Many commercial buildings have gas burners that power furnaces, roof-top units, and hot water or steam boilers. The adjustment of the burner in these heating units can have an important impact on system efficiency and fuel conservation. The burner must be adjusted using combustion test equipment to assure peak efficiency and minimum air pollution emissions. Several benefits are produced by periodic combustion efficiency testing and burner adjustment.

- The burner can be adjusted for optimum amount of combustion air for the highest combustion efficiency and reduced fuel consumption.

- Carbon Monoxide (a highly toxic gas) production by the heating equipment can be maintained at acceptable levels (typically less than 400 parts per million ).

- Heating equipment problems and efficiencies can be observed and corrected before more serious problems develop. For example, poor draft conditions can be observed and corrective actions taken before hazardous conditions develop. Also, combustion testing can help to identify inefficient heating equipment that needs to be upgraded.

The combustion test equipment includes instruments to measure the flue gas temperature, oxygen content of the flue gases, carbon monoxide levels, chimney draft, gas pressure at the burner, and other important combustion parameters. A program of frequent combustion testing and burner adjustment is recommended to assure the highest boiler efficiency and safe operation especially for buildings in size classes II and III. 


\section{REFIT OPTION: OXYGEN TRIM CONTROL}

APPLICATIONS: Commercial Buildings with Large Boilers

\section{TECHNICAL DESCRIPTION:}

Oxygen trim improves the combustion efficiency of boilers by continuously monitoring the oxygen (excess combustion air) in the flue gases, and then adjusting the burner air damper. This produces the highest practical efficiency whenever the boiler is operating. Typically, an oxygen sensor is installed in the exhaust flue and produces an electric signal that is used to adjust a variable linkage on the combustion air control shaft. As the oxygen level changes the linkage expands or contracts to maintain a constant excess air level in the burner. The cost of this system is relatively high and, therefore, it is recommended only for larger commercial boilers. However, the availability of lower cost oxygen sensors and electronic controllers may expand the use of oxygen trim to smaller-sized commercial buildings. Additional study is needed to determine if lower cost oxygen trim systems are available that are appropriate for mid-sized commercial buildings. 


\title{
REFIT OPTION: BOILER PLANT OPTIMIZATION
}

\author{
APPLICATIONS: Commercial Buildings with Central Boiler Plants
}

\section{TECHNICAL DESCRIPTION:}

Boiler Plant Optimization is a general term that applies to a number of options that can improve the operating efficiency of boiler plants in commercial buildings. These boiler plants often include multiple steam or hot water boilers and ancillary equipment, and the optimization options may include:

$\begin{array}{ll}\text { - } & \text { Automatic Boiler Selection } \\ \text { - } & \text { Oouler Isolation } \\ \text { - } & \text { Boiler Water Temperature Control } \\ \text { - } & \text { Combustion Efficiency Monitoring } \\ & \text { Condensate Return Monitoring }\end{array}$

Automatic Boiler Selection uses information on the efficiency of individual boilers and boiler combinations as a function of plant heating load to operate the most efficient boiler combination at all times. Some boilers are more efficient than others (due to combustion efficiency, convective heat losses, and boiler casing losses), and the optimum boiler combination can be determined and operated at all times to reduce annual fuel use. This selection can be based on a fixed schedule of boiler efficiencies, or an adaptive computer program that continually monitors the efficiency of the boiler plant and operates the highest efficiency boiler combination. This option is appropriate for boiler plants in class III buildings and can produce fuel savings of 10 to $15 \%$. It may also be useful in some class II size commercial buildings.

Boiler Isolation involves the physical isolation of boilers from the steam or hot water supply when the boiler is idle. This reduces the temperature of the boiler during idle times and lowers off-cycle heat losses for higher overall plant efficiency. This option can be considered for all multiple boiler heating plants. Savings will vary widely depending on the number of boilers and existing operating schedules.

Outdoor Air boiler Lockout prevents the operating of heating boilers whenever the outdoor air temperature is above a preset level $\left(55^{\circ} \mathrm{F}\right.$, for example). This lowers boiler off-cycle heat losses and fuel use by lowering the boiler temperature whenever the outdoor temperature is above the preset level and space heating is not required. In some cases, a lower boiler temperature is used if domestic hot water is supplied by the same boiler that produces space heating. This option may be useful for a wide range of commercial building sizes.

Boiler Water Temperature Control is an option that automatically reduces the temperature of boiler water as the outdoor temperature varies. As the outdoor air temperature rises, the heating load decreases, and the temperature of the boiler water is reduced based on a preset schedule. This reduces off-cycle heat losses from the boiler, improves boiler plant efficiency, 
and reduces annual fuel use. This option can be incorporated into some building Energy Management Systems if boiler plant control points are included. Otherwise, a separate outdoor air reset controller can be added to the boiler controls. The savings produced by this option depend on the design of the boiler and its off-cycle heat losses, with higher savings expected for less efficient boilers.

Combustion Efficiency Monitoring can be added to some building Energy Management Systems by installing sensors on the boiler. This permits continuous monitoring of boiler efficiency so that burner tune-ups can be performed whenever the combustion efficiency drops. This option may be appropriate for mid-size commercio buildings with EMS's that are too small for oxygen trim.

Condensate Return Monitoring is important because make-up water must be heated from about $60^{\circ} \mathrm{F}$ to 180 or $200^{\circ} \mathrm{F}$, representing a significant energy loss. Daily recording of boiler water make-up flow can identify problems with condensate return that may require condensate piping repairs. The energy savings produced can vary widely, but may reach $10 \%$ or more in some cases. 


\section{REFIT OPTION: GAS BURNER REPLACEMENT}

\section{APPLICATIONS: Commercial Buildings with Gas-Fired Heating Equipment}

\section{TECHNICAL DESCRIPTION:}

Some new gas power burners are available with improved design features including higher static air pressure that operate with higher steady state and seasonal efficiencies. These burners can be used to replace older gas burners to improve system efficiency for lower fuel use. In some cases, atmospheric gas burners, which have low combustion efficiency and high off-cycle heat loss, can be upgraded with new power gas burners. In some small commercial heating units, however, the atmospheric burner cannot be replaced by a power gas burner, and the entire burner-boiler or burner-furnace must be replaced with a higher efficiency model.

Fuel savings produced by retrofitting a high efficiency power burner in place of a less efficient model will vary depending on the efficiency of the existing burner and other sitespecific factors. The typical savings that result from improved combustion efficiency and lower off-cycle losses with the new burner is expected to fall in the range of $5 \%$ to $15 \%$. More research is needed to characterize the performance of existing gas burners (both atmospheric and power models) especially in building size class II. Size class I has been characterized by past residential conservation programs, and size class III often includes packaged boilers that include higher efficiency gas and dual-fuel burners. Guidelines are needed to assist energy auditors to identify and select burner replacements for the full range of commercial building sizes. 


\section{REFIT OPTION: PARTIAL BOILER REPLACEMENT}

APPLICATIONS: Larger Commercial Buildings with Multiple Boilers

\section{TECHNICAL DESCRIPTION:}

Many commercial buildings in size class III have more than one boiler to supply heat, domestic hot water, cooking and other functions in single buildings and multiple building complexes. In many cases two large boilers are installed that are oversized for most of the heating season. The installation of a smaller efficient boiler offers many advantages that include:

- Higher efficiency for generating domestic hot water in the summer months.

- Higher efficiency than the large boiler for intermediate (non-peak) heating months because of higher combustion efficiency and reduced off-cycle heat losses (smaller boiler casing and more efficient design)

- Lower replacement and installation costs than a large replacement boiler.

For example, an older building may have two 250 horsepower boilers to meet a peak heating demand of 200 horsepower. Most of the time even one of these boilers is too large for the load. In the summer months the domestic hot water demand requires the burner to operate only 5 to $10 \%$ of the time, producing high off-cycle heat losses, very low overall efticiency, and excessive fuel use. If one of the boilers is replaced by one high efficiency boiler rated at 50 to 100 horsepower, the domestic hot water generation efficiency can increase dramatically. In addition, this boiler can supply all the space heat needed until the coldest months of the year, reducing annual energy use for space heating. The large boiler is used only during peak heating months when it operates at its highest efficiency.

The fuel savings produced by this option can be as high as $30 \%$, but the actual savings will depend on the efficiency and oversizing of the existing boilers, the ratio of domestic hot water to space heating loads, and many other site-specific factors. However, the payback produced by this option can be as low as two years because of the relatively low cost of the smaller boiler. 


\section{REFIT OPTION: BOILER PLANT REPLACEMENT}

\section{APPLICATIONS: Larger Commercial Buildings}

\section{TECHNICAL DESCRIPTION:}

Some buildings have older inefficient boilers with excessive fuel use that are at the end of their useful life and can benefit by total replacement of the heating plant. The fuel cost savings from the new boilers can help offset the cost of the new plant. The payback produced in these cases is usually longer than for partial boiler replacement, and is often in the 3 to 10 year range. One option that is often attractive is the use of many smaller "modular" high efficiency boilers to replace one or two large boilers. The modular design offers some important advantages if installed properly:

- Higher efficiency because only the minimum number of smaller boilers are operated at any time, reducing off-cycle heat losses compared to single large boilers.

- Reliability is improved because if one boiler fails it represents only a small fraction of the heat load.

- Installation costs can be lower because the small boiler modules are easier to install in boiler rooms than single large boilers.

More research is needed to characterize the efficiency of mid-sized gas heating equipment in commercial buildings and to identify and evaluate energy conservation measures (such as high efficiency modular boilers) that can be applied to these buildings. 

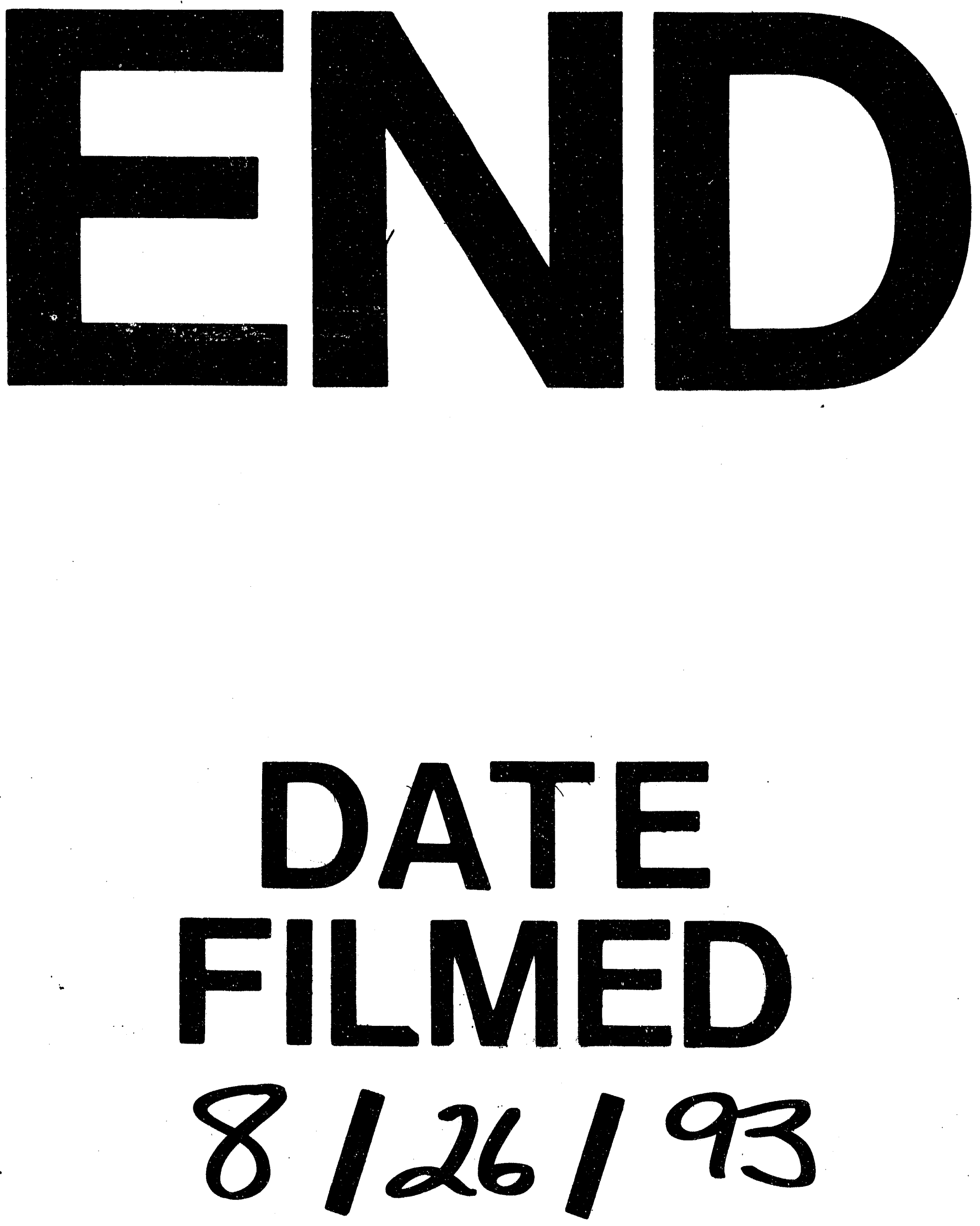
